\title{
Governance and Local Economic Development in Three Southern African Countries: Namibia, South Africa and Zimbabwe
}

\section{Prudence Khumalo}

\section{Abstract}

The Local Economic Development (LED) terrain in Southern Africa is punctuated by a high attrition rate of initiatives, which triggers both development practitioners and scholars to search for solutions to this challenge. This work explores the centrality of Governance in the process of LED implementation. The thrust of the work is to explore governance issues that may help improve economic development performance of localities in Southern Africa. The article unpacks both concepts with a goal of uncovering essential linkages so as to determine what entails good governance for LED. Despite its popularity as one of the vehicles to attaining Millennium Development goals, LED has had a number of setbacks in its implementation. This work endeavours to critically examine the aspect of governance as a key factor in the success of LED. Using lenses of bottom-up approach to development, the governance challenges are discussed as some of the main setbacks to the success of LED in the region. Subsequently, the article discusses the possible ways of strengthening governance for the success of Local Economic Development.

Keywords: Governance, Local Economic Development, Southern Africa, partnership, public responsiveness, implementation.

\section{Introduction}

There has been a lot of work done to attain freedom and independence in Africa 
and in other parts of the world. Politically a number of formally colonised states are enjoying self rule, however, this has not simultaneously brought economic development as anticipated. Nyong'o (2001:4) writes that the number of the poor in Africa has been increasing since independence. This is partly due to the fact that local economies are affected unprecedentedly by policies and processes formed at an international level such as market liberalisation, expanding global trade and the dynamics of international trade (ILO 2006.2). As observed by Rogerson and Rogerson (2010.1) policy debates on Local Economic Development (LED) mainly focus on the role of lower levels of government, however, national governments have an essential set of functions to support LED. It could be drawn from the words of the former United Nations secretary; Kofi Annan that governance is probably a highranking aspect in the pursuit of economic development (Abdellatif 2003:3). The purpose of this article is to evaluate those functions related to governance. Governance has been part of the top of the policy agenda in Sub-Saharan Africa due to crises the region has experienced (Sebudubudu 2010:251).

The work focuses on three countries, Namibia, South Africa and Zimbabwe. The three countries make about a fifth of the total number of Southern African Development Community (SADC) countries and were randomly selected to give an appreciation of the LED and governance issues obtaining in the region. South Africa was of interest to the study because of its position as the last of the group to become independent. The interest on Zimbabwe was its gaining independence in the same year the group was formed, by then called the Southern African Development Coordination Conference (SADCC). Namibia got its independence two years before the regional block changed from SADCC to SADC so it marks the transition period. Given the fact that LED became popular in Africa in the recent years, particularly the 1990's (Patterson 2008.3, Rogerson and Rogerson, 2010.3), the three countries being some of the last to get their independence were expected to have a more defined framework for LED, building on the experience of their neighbours.

Attainment of majority rule in the region brought high hopes to the citizens who were long subjected to socio-economic marginalisation. While strides have been made politically and socially, many people in Southern Africa are engulfed in abject poverty. The failure of Structural Adjustments and other macro-economic policies to improve the lives of the majority in this region has seen governments adopt LED as a possible move towards economic 


\section{Prudence Khumalo}

empowerment. The article argues for strengthening the role of the state as a way of improving the outcomes of LED endeavours. In doing so, LED and governance are discussed and the relationship between the two is established. Subsequently, LED implementation and governance in each of the three countries is briefly analysed and evaluated in order to bolster the thesis that governance has a bearing on LED. Consequently, the possible ways of reinforcing governance are discussed drawing from the synthesis of the cases of three countries.

\section{Local Economic Development}

LED can be viewed as a process in which local governments or communitybased organisations engage to stimulate or maintain business activity and employment opportunities in sectors that improve the community, using existing human, natural and institutional resources (Moyo 2007:221). Nel and Rogerson (2005:1) assert that LED can be viewed as a locality-based response to globalisation challenges, devolution and local level opportunities and crises. LED offers a means to counteract or take advantage of the forces of globalisation by maximising local potential (ILO 2006:2). The features of globalisation like market liberalisation are seen as key drivers in the manner local development is planned (Rogerson \& Rogerson 2010:2). Whether poor or rich, local entities in a global economy have the challenge and the opportunity to shape their economic future (Blakley \& Leigh 2010:1).

The few definitions highlighted can be summed up in the International Labour Organiation's key features of LED which include participation and social dialogue, focus on territory, 'mobilisation of local resources and competitive advantages, and the imperative for high levels of ownership and management' (ILO 2006:2). LED in this article is therefore summed up as a process of improving the locality as a place of doing business which involves collective action from government, the private sector, non-governmental organisations and the community. The main aim being the improvement of people's standard of living. Rogerson and Rogerson (2011:3) point out that,

although the activity of LED embodies clear economic focus, it is not all about economic growth but should be targeted at a sustainable development pattern which accommodates and reconciles economic, social and ecological issues and objectives. 
LED is to be pursued with a clear appreciation of the territorial features because its implementation largely depends on the local factors. This feature of LED makes it unwise to import strategies from one place to another without carefully reconciling them with the prevailing environment. The acceptability of LED as an approach to deal with issues of poverty is its promise of wide participation where the development process is democratised within a defined context. As noted by Mutekede and Sigauke (2007:17) the focus of LED practiced in the global South differs from the one in the North in that the former emphasises the fight against poverty as one of the key policy features. This is understandable firstly, considering the high levels of inequality and abject poverty haunting the South. Secondly by its nature LED planning approaches are distinguished from the traditional development approaches in their focus on a defined territory (Nel \& Rogeson 2005:1). The differences in the socioeconomic environments of the global North and the global South impacts on the forms of governance and LED strategies employed.

It is noted here that given the territorial emphasis highlighted in a number of definitions LED has tended to be viewed as a sub-national units' responsibility, yet the central state has a oftentimes interpreted in a limited way as special activities undertaken by government or non-governmental entities, to catalyse economic development but in essence all government activity has a bearing on LED.

\section{Governance}

The concept of Governance in a generic sense relates to the task of running a government (Nsibambi 1998). It describes the

exercise of economic, political and administrative authority to manage a country's affairs at all levels. It comprises processes and institutions through which groups articulate their interests, exercise their legal rights, meet their obligations and mediate their differences (Abdellatif 2003:4).

The focus of this article however, is to establish what constitute good governance for local economic development. Good governance is therefore associated with, 


\section{Prudence Khumalo}

prevalence of legitimacy of authority, public responsiveness, public accountability, partnerships between government and civil society organisations, information openness and public management effectiveness (Matovu 2002:123).

Stoker (1998:22) opines that,

governing from the governance perspective is always an interactive process because no single actor, public or private, has the knowledge and resource capacity to tackle problems unilaterally.

On a similar conceptualisation Stame (2004:8) points out that,

governance has also come to mean cooperative form of government by networks of public and private actors who participate in a negotiated decision and implementation as opposed to the traditional hierarchical model of government which is seen as unable to overcome its innate inefficiency and lack of transparency.

Scholars on governance research provide various explanations about good governance (Liou 2007:4), however, for the purpose of this work a conceptual understanding of the subject is derived from Stoker's 5 propositions. The propositions are quite handy in bringing out some key elements of governance which will assist in exploring a better appreciation of the term.

Stoker (1998:19) notes that governance is an intricate set of establishments and players from within and outside government. This proposition realises the multiplicity of centres of power and diverse links between many agencies of government at local, regional, national and supranational levels as opposed to a traditional view of one centre of power. Secondly, the concept could be viewed in terms of its focus, and Stoker writes that governance recognises the not so clear boundaries and responsibilities for addressing social and economic issues. In this case governance is linked to the concerns about social capital and the social elements necessary for effective economic and political performance (Stoker 1998:21).

Stoker's third proposition is that 'governance identifies the power dependence involved in the relationships between institutions involved in collective action'. This denotes the bringing in of multiple players each 
contributing to the realisation of a common goal. In a governance relationship no one organisation take control of a particular process of exchange (Stoker 1998:22). The essence is that different players have strength on different areas which makes collective action the way to go and interdependence inevitable. In order to meet its obligations, the local municipality has to partner with the higher spheres or levels of government and also work together with the business and not-for profit organisations. This proposition acknowledges the different forms of partnerships obtaining in governance.

The fourth proposition raises the issue of autonomy. Governance is looked at as 'autonomous self-governing networks of actors'. Stoker explains that 'under governance the ultimate partnership activity is the formation of self-governing networks'. The networks have 'a significant degree of autonomy, yet government, while not occupying a sovereign position, can indirectly' and imperfectly steer networks (Stoker 1998.24).

The fifth interpretation states that governance recognises the capacity to get things done which does not rest on the power of government to command or use its authority. It sees government as able to use new tools and techniques to steer and guide. Stoker's five elements of governance are comparable to Peters and Pierre (1998:225)'s four, namely, importance of networks, shift from control to influence, building public and private resources and the use of multiple Instruments. Stoker's first two elements are synonymous to Peters and Pierre's importance of networks and the rest are interpreted almost the same way.

\section{Approaches to Good Governance}

Two main approaches to the understanding of good governance can be drawn from scholarly work; the market and the state. The difference between the two approaches is on the role of the state. Market driven or neo-classical approaches 'emphasise the role of foreign trade and investment and the importance of a free market in stimulating competition during the development process' (Liou 2007:32). This approach views development challenges as resulting from extensive government intervention. The statist approach underline that the success of newly industrialised countries is related not to the free market but also an active state role in directing public and private resources for development (ibid:32). Kliksberg (1999:15) argues that neither extreme is beneficial instead a balanced approach that can fully exploit their 


\section{Prudence Khumalo}

complementarities is desirable. Furthermore, Kliksberg argues that countries that have managed to combine the two approaches are among the most advanced in the world.

The concept of good governance has been treated with contention in the African context where there is suspicion on the intents of its proponents. The extreme end of market approach that sought to curtail the role of the state influenced the concept of good governance presented to the developing countries (Nyerere 1998). The idea of good governance has been popularised in the continent by the donor community. The Inter-Monetary Fund and the World Bank have brought up the concept to denote the necessary reforms that the less developed countries should meet in order to realise their developmental needs and qualify for the assistance these institutions offer. The mistrust on the whole concept in the region could be summed up in Julius Nyerere's words, when he said,

It was this aid-related discussion of good governance, a matter between aid givers and aid seekers, and the arrogant and patronising manner in which it was raised by the aid givers that discredited the whole subject in the eyes of many of us in Africa and other parts of the South. For used in this manner, good governance sounded like a tool for neocolonialism. We have therefore tended to despise the concept even as, out of necessity, we try to qualify under it (Nyerere 1998).

It is essential to note that though there is a contention on the definition of the concept, the African leader underlined the fact that it cannot be disputed that a lot of African problems arise from bad governance.

I believe that we need to improve governance everywhere in Africa in order to enable our people to build real freedom and real development for themselves and their countries (Nyerere 1998).

The kind of governance that the Pan African leader advocated is not the weakening of the already weak state but rather the mechanisms that will enable the state to serve its people better. The description concurs with the fifth proposal of governance by Stoker, which allows the government to use new tools to steer, guide development and be able to intervene on behalf of the weak. 
As pointed by Klisberg (1999: 20) good governance approach is wider than the 'State-versus-market' dichotomy instead it involves cooperation among the main social actors and active integration of the powerful latent forces of civil society which both extremes tended to marginalise.

\section{Governance and Local Economic Development}

Having defined the concepts there is a need to spell out the linkages between them, how the two are related and the implications thereof. Scholarly work on governance and LED such as the one presented in the following lines suggests a strong relationship between economic development and governance. Timjstra and Rodquez-pose (2005:6) identify 4 pillars in facilitation of LED. These include territory, sustainability, governance and integration. Werlin (2001:1) 'argues that the difference between poor countries and rich countries has to do with governance challenges rather than resource issues'. It is clear that the new governance approach to economic development has changed the traditional role of government intervention and operation by introducing innovative concepts and strategies to the public management system which if applied appropriately will make significant impact to economic development policies (Liou 2007:9). The growing need to involve the people in development planning and implementation brings Local Economic Development and good governance into one basket.

The increased realisation of the need for active participation has necessitated a kind of governance that makes it possible to have a bottom-up development (Mutekede \& Sigauke 2007:2). Most countries in Africa following attainment of independence have embarked on measures to promote good governance. The early reforms focussed on restructuring the state so as to create room for more citizen participation on issues of governance. Post independent governments,

in the region have been advocating decentralisation not only as a means for the expansion of democratic space and the active involvement of the citizens in the development endeavour, but also for good governance and the economic development of localities (Matovu 2003:121).

There has been a general belief that decentralisation of power between 


\section{Prudence Khumalo}

the central state and its sub units will lead to good governance. Liou (2007:10) observes that the first major change in the good governance approach is the importance of decentralisation policies emphasised in many developed and developing countries. Decentralisation has grown to be seen as a critical element of good governance (Liou 2007:9). It involves the transfer of responsibility for planning, management, and the raising and allocation of resources from the central government and its agencies to field units of government agencies; subordinate units or levels of government; semiautonomous public authorities; or nongovernmental private or voluntary organisations (Liou 2007:10). Through decentralisation the local spheres or levels of government have become important as facilitators of local economic development. Chikulo (2010:1) points out that,

... since the 1990s, a critical objective of governance reform has been the strengthening of local government by the decentralisation of powers, resources and responsibilities to local authorities and other locally administered bodies.

This type of governing is seen to be better able to cope with the current predicaments of demographic revolution, economic decline and globalisation that make centralised decisions difficult and demand a better understanding of an intricate world (Stame 2004:8).

The creation of a comprehensive governance atmosphere creates the starting point or foundation for LED activities (Rogerson \& Rogerson, 2005:230). Understanding of good governance recognises the necessity of partnership in attainment of goals which factor is crucial for local economic development. The growing realisation that the central state does not have the adequate resources to meet its socio-economic development obligation makes the idea of partnerships very important. It is this same concept of partnership that most LED initiatives thrive on. The working together of different players, spheres of government, the private sector, NGOs and community organisations brings about strength that a single player cannot have.

The aspect of participation in development is a central issue in good governance and is a key factor in Local Economic Development. The effectiveness of LED strategies lies to a great extent, on the availability of appropriate local and regional institutional systems and on the availability of the important frameworks and skills level at all government spheres 
(Rodriguez-Pose \& Tijmstra 2005:8). The relationship between LED and good governance is therefore that the latter is critical for the success of the former.

\section{Local Economic Development and Governance In Namibia}

Local Economic Development in Namibia is still in its infancy (Geseb 2008:4), with very few policy guidelines directly dealing with the subject. Since independence the policy and regulatory environment for LED has not been much debated and it has not been made a core mandate of municipalities (Heideman 2011:7). The earlier LED efforts were restricted to provision of service, land for business and Industrial premises for development purposes (Geseb 2008:4).

\section{Policy and Legal Framework}

Policies like the Decentralisation and Enablement Act have in a way opened room for the furtherance of LED endeavours. The Act provides for the decentralisation of the central government functions to the sub-national units and gives guidelines for the establishment of consultative structures at the regional and local levels like the Rural Development Coordinating Committee (RDCC) (Geseb 2008:5). Like some of its neighbours Namibia's LED is affected by the spatial legacies of the colonial era as much of its current land use has conformed to that of its neighbours (Hiedman 2011:7).

LED in Namibia is currently guided by the National Development planning, the Regional Development act, Local and Regional Councils Acts, Decentralisation and Enablement Act (Geseb 2008:5). Recently the Country saw the tabling of a Local and Regional Development White paper in Parliament. The White paper is seen as huge progress towards an enabling policy environment for LED in the country. The Minister of Regional and Local Government, Housing and Rural Development, Jerry Ekando articulated the philosophy behind the policy stating that,

the White paper is firmly based on the understanding that while national efforts are geared towards the enhancement of greater global competitiveness, it is at the local and regional levels that opportunities are identified and harnessed (The Nambian 2011). 
Crucial to LED promotion in Namibia is the National Policy on PublicPrivate partnerships which serve as a tool for regional and local governments for the facilitation of public-private partnerships. The public-private partnerships can be on any mandated responsibility of the local government while pro-poor partnerships aimed at improving access to the poor or which will engage them in the rendering of services, thereby providing employment are prioritised (Geseb 2008:6).

The Ministry of Trade and Industry and the ministry of Regional and Local Government, Housing and Rural Development are working on policies that have a direct bearing on LED (Geseb 2008:6). The International Development agencies particularly the GTZ (German Technical Corporation) has supported LED policy development and strategies (Hiedman 2011:7).

\section{Governance and Related Challenges}

One of the main challenges facing LED in Namibia is the lack of adequate policing around the whole subject. One hopes that the White paper on LRED leads to meaningful and strategic LED implementation. As identified by the Namibian government (The Namibian 2011), there has to be a move from the current top down approach to development to a more participative bottom up approach that the White Paper seeks to provide for.

\section{Governance and Local Economic Development in South Africa}

Since the democratic elections in 1994 the South African government embarked on many transformations so as to enhance governance and people driven development drawing from the constitution to the Acts and White papers. While some scholars have recorded the huge failures of the initiatives aimed at boosting LED in South Africa, the policy framework is quite advanced than in most of the African states. One of the strengths in terms of policy is that the issue of LED is a core function of local government and there is a continuous debate among policy makers, practitioners and scholars on how best the local sphere can succeed in carrying out this mandate. This is evidenced by a number of policies and guidelines that have been enacted and tried in the search for a working formula for LED. 
In terms of governance the functioning of local government as a separate sphere of government places opportunities for a people led and owned development. This is critical as argued by Lutz and Linder (2004:4) 'that successful decentralisation is not just about building good political institutions' but also improving overall governance, which creates a democratic space for participation. It is within a framework of participation of the local population that issues of transparency, accountability and responsiveness, which are essential for meaningful effective policy implementation, are achieved. The constitutional positioning of local government is critical for LED. In 1996 the South African constitution obliged local government to ensure that they promote LED. The later policies and legal documents further interpreted the constitutional articulations with the White paper on Local Government of 1998 providing for a developmental local government which places LED as a key function of municipalities. Furthermore, the LED function became a key priority area which forms an important part of municipal plans as provided for in the Municipal Systems Act 32 of 2000. While the local government is positioned to be the facilitator of LED the other two spheres have a role to play. The move to make LED work has continued in South Arica and this has seen the drawing of the LED framework in 2006 whose purpose is to guide implementation of LED. A number of state departments fund and support LED and besides these, there are non-governmental and international organisations like GTZ that support LED.

Despite a fertile policy and legal environment for LED the country has a number of obstacles to overcome in order for significant economic progress to be realised. One of the hindrances faced is the weak LED units in the local government (Khumalo 2010:180). This has made it difficult to mobilise and co-ordinate the different stakeholders into meaningful partnership for LED, resulting in disjointed initiatives, which are often unsustainable. Despite the presence of a number of partners in LED, failure to turn policies into workable strategies has stifled LED impact. Khumalo (2010:182) observes that lack of leadership will and capacity issues still stifle LED success in South Africa.

Generally it could be argued that in most African states decentralisation has not brought about the sought after development at the local level. Matovu (2003:121) submits that decentralisation efforts have in the majority opf cases kept substantial power at the hands of the central government elite and their local allies. This has in a way seen no realisation of LED in most African states despite the myriad decentralisation schemes (ibid: 121). 


\section{Prudence Khumalo}

\section{Governance and Local Economic Development in Zimbabwe}

Following attainment of Independence in 1980, a number of reforms took place to set up a people owned development and government in Zimbabwe. Mutekede and Siagauke (2007:25) observe that in terms of Policy the coming in of the Urban Councils Act (1980), which repealed a previous Urban Councils Act, brought in some significant changes to local governance. This saw former African Townships included into the mainstream municipal system, which gave lodgers freedom to participate in elections (Mutekede \& Sigauke 2007:24). The repeal of the African Councils Act by the District Councils Act (1988) brought together 240 incapacitated African Councils into 55 lager and more viable District Councils in rural spaces (Mutekede \& Sigauke 2007:25). This development gave the districts a wide range of powers and they were brought under the Ministry of Local Government.

A significant opening of the democratic space took place in 1984 with the Prime Minister's Directive, which set out development structures from village level to provincial strata. This brought about the formation of Village Development Committees (VIDCOs) and 1000 Ward Development Committees (WADCOs) whose members were voted into positions (Mutekede $\&$ Sigauke 2007:24). While the ward structures exist in Urban Councils they are not contained in any law. The transfer of responsibilities and power from national government was attempted through the establishment of Rural District Councils provided for in the Rural District Councils Act of 1998, however, this move was critiqued as a process of counterfeit decentralisation producing RDCs lacking in power and resources with unfunded mandates (Ashely et al. 2008:4). Furthermore, this move was discredited as central government's instrument of having control of the rural majority and 'has been characterised as an exercise geared more towards attracting money from donors' (Ibid:4).

One plausible outcome of decentralisation in as far as LED is concerned is in the area of natural resource management, where local communities have room to participate and benefit from local resources like wild life. Through the Communal Areas Management Programme for Indigenous Resources (CAMPFIRE) local populace have been able to participate in management of local resources and the funds from this programme has had a significant impact on development planning and management at both district and local levels (Conyers 2003:2). 
In terms of LED funding, the following became some key sources at the district level:

- District Development Grant (DDGs) meant for rural local authorities through the Ministry of Local Government, Public Construction and National Housing (MLG) as part of a donor-funded capacity building programme;

- Rural Development Fund (RDF) sourced by the Ministry of Rural Resources and Water Development to support local infrastructure projects;

- Community Action Plan (CAP) established under the auspices of World Bank as part of the country's social dimensions of adjustment programme set to provide funding for small, community-based projects in the poorest districts; and

- Urban Development Programme (Urban II) funded by the World Bank and administered by MLG, provided funding to urban local authorities for infrastructure projects (Conveyer 2003:2).

All this funding was put on hold due to Zimbabwe's economic and political challenges (Conyers 2003:2). Given the limited powers of local governments to generate their own revenue the macro-economic and political environment prevailing in the country has stifled LED. LED is not specifically stated in Government policy in Zimbabwe though the few decentralisation policies discussed provide for structures like the District Development Committees (DDCs) and the VIDCOs whose purpose is to spearhead local development.

Mutekede and Sigauke (2007:25) observe that party politics has had a huge bearing on local governance in Zimbabwe and that the dominance by party politics is one of the hindrances to citizen participation in local governance. As a result, voter apathy is rampant in council elections as citizens cite unfulfilled promises, lack of meaningful choices, lack of economic democracy and despair at the widespread abuse of power Mutekede and Sigauke (2007:25). On a similar assessment Conyers (2003:1) writes that despite the structural reforms and decentralisation since 1980 little effective power has been decentralised. Other factors hindering successful LED in 


\section{Prudence Khumalo}

Zimbabwe include unclear roles of institutions operating at the local level. A policy vacuum exist in terms of clarifying the role of the District Development Committee, lack of formal decentralisation of functions to the sub-district levels (Mutekede \& Sigauke 2007: 26). Furthermore, citizens' inadequate knowledge of their rights and responsibilities worsens the situation.

\section{Summary of Findings}

The aspects of governance and LED in the three countries are summarised in a tabular form below using Peters and Pierre (1998:225-7)'s elements of Governance.

\begin{tabular}{|c|c|c|c|c|}
\hline & $\begin{array}{l}\text { Elements of } \\
\text { Governance }\end{array}$ & Namibia & South Africa & Zimbabwe \\
\hline 1 & $\begin{array}{l}\text { The integral } \\
\text { role of } \\
\text { networks (i.e. } \\
\text { the use of } \\
\text { networks to } \\
\text { dominate } \\
\text { public policy) }\end{array}$ & $\begin{array}{l}\text { The policy on } \\
\text { Public-Private } \\
\text { partnerships } \\
\text { encourages } \\
\text { networking } \\
\text { between } \\
\text { government } \\
\text { and the } \\
\text { private sector. }\end{array}$ & $\begin{array}{l}\text { Multiple } \\
\text { players } \\
\text { contribute to } \\
\text { public policy } \\
\text { through } \\
\text { debates and } \\
\text { lobbying. } \\
\text { Through } \\
\text { structures like } \\
\text { Intergovernm } \\
\text { ental } \\
\text { Relations } \\
\text { (IGR) LED } \\
\text { implementatio } \\
\text { n is } \\
\text { coordinated. } \\
\text { However, } \\
\text { these } \\
\text { structures } \\
\text { have not lived } \\
\text { up to their } \\
\text { expectations. }\end{array}$ & $\begin{array}{l}\text { Public policy } \\
\text { has grown to } \\
\text { be dominated } \\
\text { by political } \\
\text { parties, } \\
\text { stifling wider } \\
\text { networks with } \\
\text { other entities. }\end{array}$ \\
\hline
\end{tabular}


Governance and LED in Namibia, South Africa and Zimbabwe

\begin{tabular}{|c|c|c|c|c|}
\hline 2 & $\begin{array}{l}\text { Shift from } \\
\text { control to } \\
\text { influence (i.e. } \\
\text { government's } \\
\text { influence } \\
\text { through a } \\
\text { continual } \\
\text { process of } \\
\text { bargaining and } \\
\text { persuasion) }\end{array}$ & $\begin{array}{l}\text { The pro-poor } \\
\text { partnerships } \\
\text { aimed at } \\
\text { engaging the } \\
\text { disadvantaged } \\
\text { and giving } \\
\text { them access } \\
\text { are an } \\
\text { indication of } \\
\text { the move } \\
\text { from control } \\
\text { to influence. } \\
\text { However, } \\
\text { ineffective } \\
\text { structures } \\
\text { provided by } \\
\text { the } \\
\text { decentralisati } \\
\text { on policy } \\
\text { affect } \\
\text { stakeholder } \\
\text { involvement. }\end{array}$ & $\begin{array}{l}\text { LED is } \\
\text { facilitated by } \\
\text { the Local } \\
\text { sphere of } \\
\text { Government } \\
\text { and the other } \\
\text { spheres and } \\
\text { private } \\
\text { entities are } \\
\text { active through } \\
\text { mechanisms } \\
\text { like the } \\
\text { Integrated } \\
\text { development } \\
\text { planning. }\end{array}$ & $\begin{array}{l}\text { Local } \\
\text { Economic } \\
\text { Development } \\
\text { is sector- } \\
\text { driven and } \\
\text { controlled. }\end{array}$ \\
\hline 3 & $\begin{array}{l}\text { The blending of } \\
\text { public and } \\
\text { private } \\
\text { resources( the } \\
\text { importance of } \\
\text { network } \\
\text { framework) }\end{array}$ & $\begin{array}{l}\text { National } \\
\text { Policy on } \\
\text { Public-Private } \\
\text { partnerships } \\
\text { provides an } \\
\text { important tool } \\
\text { for the } \\
\text { facilitation of } \\
\text { partnership } \\
\text { between } \\
\text { public and } \\
\text { private } \\
\text { organization } \\
\text { in local and }\end{array}$ & $\begin{array}{l}\text { Public and } \\
\text { Private } \\
\text { organizations } \\
\text { participate in } \\
\text { LED. }\end{array}$ & $\begin{array}{l}\text { The move } \\
\text { through the } \\
\text { Ministry of } \\
\text { Youth and } \\
\text { Development } \\
\text { to introduce } \\
\text { community } \\
\text { ownership } \\
\text { schemes is } \\
\text { bent at } \\
\text { blending } \\
\text { public and } \\
\text { private } \\
\text { resources; }\end{array}$ \\
\hline
\end{tabular}




\begin{tabular}{|l|l|l|l|l|}
\hline & $\begin{array}{l}\text { regional } \\
\text { development. }\end{array}$ & $\begin{array}{l}\text { however, this } \\
\text { move faces } \\
\text { resistance } \\
\text { from the } \\
\text { private sector } \\
\text { as it is a direct } \\
\text { order from } \\
\text { Government. }\end{array}$ \\
\hline 4 & $\begin{array}{l}\text { The use of } \\
\text { multiple } \\
\text { instruments ( in } \\
\text { developing and } \\
\text { implementing } \\
\text { public policies) }\end{array}$ & $\begin{array}{l}\text { LED tends to } \\
\text { be urban } \\
\text { the fact that } \\
\text { the higher } \\
\text { category } \\
\text { Municipalities } \\
\text { (part I and II) } \\
\text { are the ones } \\
\text { that expend } \\
\text { the needed } \\
\text { resources to } \\
\text { participate in } \\
\text { LED planning } \\
\text { or capacity } \\
\text { building } \\
\text { initiatives. }\end{array}$ & $\begin{array}{l}\text { LED Policy is } \\
\text { developed } \\
\text { and } \\
\text { implemented } \\
\text { using public } \\
\text { and private } \\
\text { partnerships. } \\
\text { are used. }\end{array}$ & \\
\hline
\end{tabular}

\section{Lessons from the Three Countries}

The way that decentralisation structures are organised and how the decentralisation policies are affected determines the resources available at the local level and the roles of local governments (Lutz \& Linder 2004:2). Decentralisation for the purpose of qualifying for donor funding like in the case of Zimbabwe has not meaningfully empowered local government in facilitating LED. In terms of structural positioning, the South African status of local government as a sphere not a layer of government is more ideal for LED. Sound participation of all important actors at the local level is key to successful local development as this allows the influential structures to work together. A 
policy framework that specifies the role of different spheres of Government is essential for a collective and well co-ordinated LED implementation. Given capacity limitations of most governments, conducive governance is essential for ensuring fruitful partnerships with other stakeholders. This concurs with Kliksberg (1999:30)'s idea of 'smart government' which can 'work in harmony with forces of private enterprise to achieve optimum results for the country and promote and facilitate the development of an increasingly close-knit, strong and active civil society'.

\section{Conclusion}

The article has discussed LED and governance, bringing out that the later is essential for the successful implementation of the former. The state of LED in Namibia, South Africa and Zimbabwe has been briefly discussed to identify some governance challenges hindering successful LED in Southern Africa. These include among others, inadequate policy on LED, poor resource allocation to sub-national units, capacity issues, weak sub-national units and in some cases top-down approach to LED implementation. The article has underlined the need for adequate policy around LED, a democratised approach to development that will capacitate local government to facilitate LED and an enabling form of governance that allows various stakeholders to actively participate in LED.

\section{References}

Abdellatif, A.M. 2003. Good Governance and its Relationship to Democracy and Economic Development: UNDP Workshop IV, POGAR, Seoul, United Nations Development Programme.

Ashley, C., C. Joseph, L. Edward, M. Zefanias, L. Mehta, M. Kgopotso, M. Solomon, M. Sobona, N. Isidla, N. Alan, N. Simon, N. Zolile, P. Joao, S. Ian, S. Shaila \& W. Wolmer (The SLSA Team) 2008. The Politics of Decentralisation in Southern Africa. Future Agricultures Consortium Policy Briefing for WDR.

Bartik, T.J. 2003. Local Economic Development Policies. Michigan: Upjohn Institute Staff working paper No.03-91.

Blakley, E.J. \& L.N. Green 2010. Planning Local Economic Development: 
Theory and Practice. $4^{\text {th }}$ Edition. Los Angeles: Sage Publications, Inc. Chikulo, B. 2009. Local Governance Reforms in Zambia. Commonwealth Journal of Local Governance Issue 2.

Conyers, D. 2003. Decentralisation in Zimbabwe: A Local Perspective. Public Admin. Dev. 23: 115 - 124.

Geseb, S. 2008. Local Economic Development Network Africa (LEDNA) LED Stocktaking Survey. Report on the State of LED for Namibia. Work Supported by GTZ/Partnership Economic Growth (PEG) in Namibia.

Hiedeman, L. 2011. Municipal Local Economic Development and the Power of the Local Multiplier Effect: Piloting a Community Enterprise Identification Method in South Africa and Namibia. P3 Project funded by European Union and Swedish International Development Agency. Available at: www.projectp3.org (Accessed on 12 February 2012.)

Khumalo, P. 2010. Local Economic Development Policy implementation in Amathole District. Unpublished PhD, thesis University of Fort Hare.

Klisberg, B. 2000. Rethinking the State for Social Development: Towards

'Smart Government'. International Review of Administrative Sciences 66: $241-257$.

https://doi.org/10.1177/0020852300662002

Liou, K.T. 2007. Applying Good Governance Concept to Promote Local Economic Development: Contribution and Challenge. International Journal of Economic Development 9,1 \& 2: 1 - 31.

Lutz, G. \& W. Linder 2004. Traditional Structures in Local Governance for Local Development. Berne, Switzerland: Institute of Political Science.

Matovu, G. 2002. Policy Options for Good Governance and Local Economic Development in Eastern and Southern Africa. Urban Forum 13,4.

https://doi.org/10.1007/s12132-002-0018-X

Moyo, T. 2007. Leadership Challenges for Successful Local Economic Development in South Africa. Journal of Public Administration 42,3: 220 -230 .

Mutekede, L. \& N. Sigauke 2007. Policy Options for Participatory Governance and Local Economic Development in Africa. Africa Local Government Action Forum Phase VII: Linking Participatory Governance to Local Economic Development and Poverty Reduction. Available at: www.siteresources.worldbank.org/cmudlp/resources/policy options.pdf.

Nel, E.L. \& C.M. Rogerson. 2005. Local Economic Development in the developing World: The Experience of Southern Africa. New Brunswick 
(USA) and London (UK): Transaction Publishers.

Nel, E.L. \& C.M. Rogerson 2007. Evolving Local Economic Development Policy and Practice in South Africa with Special Reference to Smaller Urban Centres. Urban Forum July,18,2:1 - 11.

Nsibamb, A. 1998. Decentralisation and Civil Society in Uganda: The Quest for Good Governance. Kampala: Fountain Publishers.

Nyerere, J. [1998] 2008. Good Governance for Africa. In Pan-African News December 24. Available at:

http://panafricannews.blogspot.com/2008/12/julius-nyerere-on-goodgovernance-for.html. (Accessed on 20 August 2011.)

Nyong'o, A. P 2001. Governance and Poverty Reduction in Africa. Economic

Research Papers No.68. African Development Bank

ILO 2006. Local Economic Development Manual for China. Geneva: ILO.

Patterson, C. 2008. Country Report, Local Economic Development in South Africa. A Report prepared for German Technical Cooperation (GTZ), Strengthening Local Government Programme's LED component, South Africa.

Peters, B.G. \& J. Pierre 1998. Governance without Government? Rethinking

Public Administration. Journal of Public Administration Research and

Theory 8,2: 223 - 243.

https://doi.org/10.1093/oxfordjournals.jpart.a024379

Rogerson, C.M. \& J.M. Rogerson 2010. Local Economic Development in

Africa: Global context and research directions. Development Southern Africa 27,4: 465 - 480.

https://doi.org/10.1080/0376835X.2010.508577

Rodriguez-Pose, A. \& S. Tijmstra 2005. Local Economic Development as an Alternative to Economic Development in Sub-Saharan Africa. Paper Prepared for the World Bank-Netherlands Partnership Programme, Evaluating and Disseminating Experiences in Local Economic Development, World Bank, Washington.

Rogerson, C.M. \& J.M. Rogerson 2011. Improving the Business Environment for Local Economic Development in South Africa. Journal of Public Administration 46,3: 995 - 1009.

RSA 1996. The Constitution of the Republic of South Africa, Act 108 of 1996.

Republic of South Africa 2000. Municipal Systems Act, Act 32 Of 2000. RSA 2006. National Framework for Local Economic Development in South Africa (2006-2011). Department of Provincial and Local Government. 
RSA 1998. White Paper on Local Government. Available at: http://www.cogta.gov.za/cgta_2016/wpcontent/uploads/2016/06/whitepaper on Local-Gov 1998.pdf

Rodriquez-Pose, A. \& S.A.R. Tijmstra 2005. Local Economic Development as an Alternative Approach to Economic Development in Sub-Saharan Africa. An unpublished World Bank Report.

Sebudubudu, D. 2010. The Impact of Good Governance on Development and Poverty in Africa: Botswana - A Relatively Successful African Initiative. African Journal of Political Science and International Relations 4,7: 249262.

Stame, N. 2006. Governance, Democracy and Evaluation. Evaluation 12,1:716.

https://doi.org/10.1177/1356389006064173

Stoker, G. 1998. Governance as Theory: Five Propositions. International Social Science Journal 155.

https://doi.org/10.1111/1468-2451.00106

Swinburn, G. 2007. Talk is Cheap: Turning Local Economic Development Strategies into Reality in Transition Countries. Bosnia and Herzegovina, Macedonia and Moldova. Budapest: Open Society Institute.

The Namibian 2011. White Paper on Local Economic Development Tabled in Parliament. Available at www.namibian.com.na (Accessed on 08 April 2011.)

Werlin, H.H. 2001. Poor Nations/ Rich Nations: Why the Difference. Paper prepared for the ASPA conference at Rutgers in Newark, NJ.

Prudence Khumalo Department of Public Administration University of South Africa South Africa khumap1@unisa.ac.za; or maqhawek@gmail.com 